\title{
METHANE OXIDATION OVER DUAL REDOX CATALYSTS
}

\author{
Quarterly Technical Progress Report \\ October-December 1991
}

\author{
Zettlemoyer Center for Surface studies \\ and \\ Department of Chemistry \\ Lehigh University \\ Bethlehem, PA 18015
}

February 1992

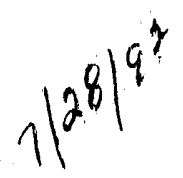

\begin{abstract}
Prepared for
U.S. Department of Energy Morgantown Energy Technology Center

Under Contract No. DE-FG21-89MC26039
\end{abstract}




\section{Disclaimer}

This report was prepared as an account of work sponsored by the United States Government. Neither the United States nor the United States DOE, nor any of their employees, makes any warranty, express or implied, or assumes any legal liability or responsibility for the accuracy, completeness, or usefulness of any information, apparatus, product or process disclosed, or represents that its use would not infringe privately owned rights. 


\section{METHANE OXIDATION OVER DUAL REDOX CATALYSTS}

\section{SUMMARY OF PROGRESS}

The effect of doping lanthana-based catalysts with antimony and bismuth on the catalytic behavior toward the selective oxidation of methane has been studied. New catalytic results have been btained upon doping the $\mathrm{Sr} / \mathrm{La}_{2} \mathrm{O}_{3}$ catalyst, obtained from AMOCO Oil Co., with the acidic Sb and Fe dopants. Both activity and selectivity of the original $\mathrm{Sr} / \mathrm{La}_{2} \mathrm{O}_{3}$ catalyst can be modified by introducing small amounts of either dopant. Iron doping lowered selectivity to $\mathrm{C}_{2}$ products whereas antimony increased the selectivity while decreasing the reaction temperature by $100^{\circ} \mathrm{C}$. 


\section{TECHNICAL PROGRESS}

\section{INTRODUCTXON}

Since methane is the major constituent of natural gas, routes involving the indirect conversion of methane to $\mathrm{CO}$ and then to oxygenates or higher hydrocarbons have been developed. However, the steam reforming process is endothermic, and it is desirable to explore other routes with more favorable thermodynamic driving force. One possible alternative is the direct catalytic oxidative coupling of methane to $C_{2}$ products, which can in turn be converted to gasoline or used as chemical feedstocks.

Lanthanum-based oxides are wel1-known recently developed catalysts for the oxidative coupling of methane toward $C_{2}$ products (1-3). The oxidative coupling of methane is a well-studied process over many different types of catalysts, and several reviews have been written on the homogeneous and heterogeneous oxidative coupling of methane (4-7). For the heterogeneous catalytic process, a great variety of catalytic materials have been reported, with the alkali and alkaline earth metals $(8,9)$, as well as the rare earth oxides (10), being the most promising and widely studled catalysts.

In this context, lanthana and rtrontla-lanthana based catalysts are considered among the most active and selective catalysts for the oxidative coupling of methane. DeBoy and Hicks $(2,3,11)$ reported selectivities to $C_{2}$ products of up to 648 and a methane conversion of 20.98 at $750^{\circ} \mathrm{C}$ for the Sr-promoted $\mathrm{La}_{2} \mathrm{O}_{3}$ catalyst. They also showed that the unpromoted $\mathrm{La}_{2} \mathrm{O}_{3}$ was less selective at those conditions. Despite the wide range of experimental conditions employed by the different research groups, which makes the comparison of results difficult, the undoped $\mathrm{La}_{2} \mathrm{O}_{3}$ oxide was always found to be less active and selective than the $\mathrm{Sr} / \mathrm{La}_{2} \mathrm{O}_{3}$ catalyst, confirming the promoting effect of $\mathrm{Sr}$.

On the other hand, several research groups have studied the catalytic 
properties of metal oxide catalysts such as $\mathrm{Fe}_{2} \mathrm{O}_{3}, \mathrm{Sb}_{2} \mathrm{O}_{5}, \mathrm{SnO}_{2}, \mathrm{PbO}$, and $\mathrm{Bi}_{2} \mathrm{O}_{3}$ and found that these oxides had low activity for the synthesis of $C_{2}$ hydrocarbons, either alone or supported on other oxides (4-6). However, relatively good selectivities were obtained with those redox oxide systems under cyclic $(12,13)$ or cofeed $(14-18)$ operations at $700-850^{\circ} \mathrm{C}$.

In this report, we report on the results obtained by promoting the $\mathrm{Sr} / \mathrm{La}_{2} \mathrm{O}_{3}$ catalyst with small, e.g. 0.5 wto, amounts of $\mathrm{Sb}$ or $\mathrm{Fe}$. Both the activity and selectivity toward $C_{2}$ products of the base catalyst were dramatically affected by the promoters, whereas Fe was found to decrease the overall selectivity, the Sb-doped catalyst exhibited higher activity and selectivities toward $\mathrm{C}_{2}$ hydrocarbons.

\section{EXPERIMENTAL}

A 1 wt: $\mathrm{Sr} / \mathrm{La}_{2} \mathrm{O}_{3}$ catalyst prepared as described in (3) was obtained from AMOCO 0 il Co. Samples containing $\mathrm{Sb}$ or Fe were prepared by aqueous impregration of the $\mathrm{Sr} / \mathrm{La}_{2} \mathrm{O}_{3}$ sample with $\mathrm{SbCl}_{3}$ or $\mathrm{Fe}\left(\mathrm{NO}_{3}\right)_{3} \cdot 9 \mathrm{H}_{2} \mathrm{O}$, respectively. After drying, samples were calcined in air at $600^{\circ} \mathrm{C}$ for $20 \mathrm{~h}$. Before the catalytic test, samples were activated in a He flow at $700^{\circ} \mathrm{C}$ for $3 \mathrm{~h}$ in order to remove any traces of water and to decompose $\mathrm{La}(\mathrm{OH})_{3}$ and surface carbonate phases that might be formed upon impregnation and calcination in air. The catalytic testing was performed at ambient pressure in the temperature range of $500-850^{\circ} \mathrm{C}$ in a continuous flow microreactor. The reactants consisted of a $\mathrm{CH}_{4}$ and air mixture with $\mathrm{CH}_{4} / \mathrm{air}=1$ molar ratio and with gas hourly space velocity (GHSV) of 70,000 $1 / \mathrm{kg} c a t / \mathrm{h}$.

\section{RESULTS AND DISCUSSION}

Catalytic results obtained with the unpromoted and the Fe- or Sb-promoted $\mathrm{Sr} / \mathrm{La}_{2} \mathrm{O}_{3}$ as a function of temperature are presented in Figure 1 . The comparative performance of the catalysts at $600^{\circ} \mathrm{C}$ is shown in Table 1. 
TABLE 1 .

ACTIVITY AND SELECTIVITY OF LANTHANA-BASED OXIDES FOR METHANE OXIDATION ${ }^{*}$

\begin{tabular}{|c|c|c|c|c|c|c|c|c|}
\hline \multirow[t]{2}{*}{ CATALYST } & \multirow{2}{*}{$\begin{array}{l}\text { METHANE } \\
\text { CONVERS ION } \\
(z)\end{array}$} & \multicolumn{4}{|c|}{$\begin{array}{l}\text { SELECTIVITIES } \\
\text { (carbon at. } 8 \text { ) }\end{array}$} & \multirow{2}{*}{$\begin{array}{l}\text { YIELD } \\
(8) \\
C_{2}{ }^{\prime} s\end{array}$} & \multicolumn{2}{|c|}{ PRODUCT RATIO } \\
\hline & & $\mathrm{C}_{2^{m^{b}}}$ & $\mathrm{C}_{2}^{\mathrm{b}}$ & Co & $\mathrm{CO}_{2}$ & & $C_{2}=/ C_{2}$ & $\mathrm{CO}_{2} / \mathrm{CO}$ \\
\hline $\mathrm{Sr} / \mathrm{La}_{2} \mathrm{O}_{3}$ & 8.8 & 5.3 & 25.3 & 23.9 & 45.4 & 2.7 & 0.2 & 1.9 \\
\hline $\mathrm{Fe} / \mathrm{Sr} / \mathrm{La}_{2} \mathrm{O}_{3}$ & 13.5 & 7.6 & 26.6 & 4.1 & 58.6 & 4.6 & 0.3 & 14.3 \\
\hline $\mathrm{Sb} / \mathrm{Sr} / \mathrm{La}_{2} \mathrm{O}_{3}$ & 23.5 & 25.2 & 32.3 & 5.0 & 34.0 & 13.5 & 0.8 & 6.8 \\
\hline
\end{tabular}

aReaction conditions: $\mathrm{T}=600^{\circ} \mathrm{C} ; \mathrm{CH}_{4} / \mathrm{air}=1 ; \mathrm{GHSV}=70,0001 / \mathrm{kg} \mathrm{cat} / \mathrm{h}$

${ }^{\mathrm{b}} \mathrm{C}_{2}=$, ethene; $\mathrm{C}_{2}$, ethane

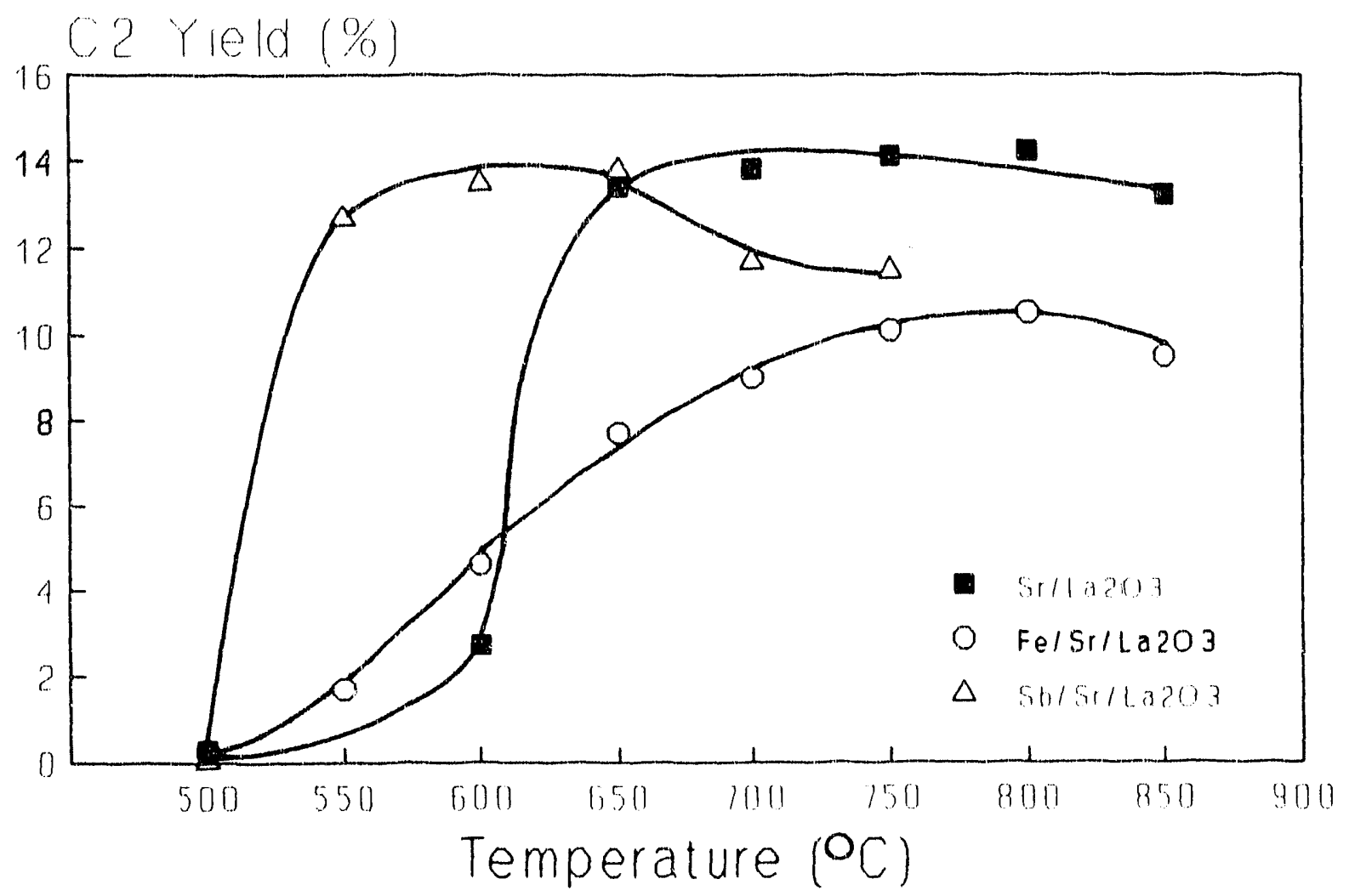

FIGURE 1. Effect of temperature on the yield of total $C_{2}$ products for the unpromoted and Lewis acid promoted $\mathrm{Sr} / \mathrm{La}_{2} \mathrm{O}_{3}$ catalysts. 
Comparison between the $\mathrm{Fe}$-promoted and the unpromoted $\mathrm{Sr} / \mathrm{La}_{2} \mathrm{O}_{3}$ catalysts indicates that $\mathrm{Fe} / \mathrm{Sr} / \mathrm{La}_{2} \mathrm{O}_{3}$ was slightly more active and selective to $\mathrm{C}_{2}$ hydrocarbons than the unpromoted oxide at temperatures lower than $650^{\circ} \mathrm{C}$. The consequent increase in the $C_{2}$ yield upon $F e$ promotion is shown in Figure 1. The ethylene/ethane ratio $\left(C_{2}=/ C_{2}\right)$ was also higher on the Fe-promoted catalyst at those low temperatures as shown in Table 1 . However, the $\mathrm{CO}_{2} / \mathrm{CO}$ ratio calculated at this temperature was one order of magnitude higher than that of the unpromoted catalyst, suggesting that the Fe-doped catalyst favors production of deep oxidation products at low temperatures. Results obtained at temperatures higher than $600^{\circ} \mathrm{C}$ showed that the Fe-doped catalyst was less active than the undoped catalyst in terms of methane conversion and produced more $\mathrm{CO}_{\mathbf{x}}$ than the unpromoted $\mathrm{Sr} / \mathrm{La}_{2} \mathrm{O}_{3}$, which led to a decrease in the total selectivity to $\mathrm{C}_{2}$ products compared to the undoped oxide. This effect is shown in Figure 1 as a lower $\mathrm{C}_{2}$ yield compare to the $\mathrm{Sr} / \mathrm{La}_{2} \mathrm{O}_{3}$. Similar results have been obtained by other workers with $\mathrm{CoO}(19)$ or $\mathrm{FeO}(20)$ doped in Li/MgO catalyst.s.

Although a sharp increase of the methane conversion in the temperature range of $550-600^{\circ} \mathrm{C}$ was observed for all the samples, the unpromoted $\mathrm{Sr} / \mathrm{La}_{2} \mathrm{O}_{3}$ reached the highest conversion level at about $650^{\circ} \mathrm{C}$, whereas the $\mathrm{Sb}$-promoted satalyst showed complete oxygen depletion at $550^{\circ} \mathrm{C}$, indicating that the Sb dopant significantly lowered the reaction temperature. The antimony-doped sample showed the highest activity of this series of catalysts. As shown in Table 1, high selectivities toward $\mathrm{C}_{2}$ products were obtained with the Sb-doped catalyst, with the $C_{2}=/ C_{2}$ molar ratio being four times higher than that of the undoped catalyst. Clearly, $\mathrm{Sb}$ enhances selectivity to $\mathrm{C}_{2}$ products at low temperatures by depleting production of $\mathrm{CO}$ and $\mathrm{CO}_{2}$. A.t temperatures higher than $700^{\circ} \mathrm{C}$, the $\mathrm{Sb}$-doped catalyst lost antimony by volatilization and showed an increasing selectivity to $\mathrm{CO}_{2}$. A striking feature of the performance of this sample was that the 
volatilization process led to methane conversions and selectivities toward $\mathrm{C}_{2}$ products lower than those of the unpromoted $\mathrm{Sr} / \mathrm{La}_{2} \mathrm{O}_{3}$ at those temperatures, suggesting that in that process the deactivation of the active sites responsible for the generation of methyl radicals was also involved, and was probable caused by the spreading of a melt film of $\mathrm{Sb}$ on the surface of the $\mathrm{Sr} / \mathrm{La}_{2} \mathrm{O}_{3}$ base catalyst.

For all three catalysts, a linear increase in the $C_{2}=/ C_{2}$ ratio was observed with increasing temperature, although the Sb-doped catalyst showed the highest ratio at temperatures up to $750^{\circ} \mathrm{C}$, reaching a value of 1.01 at that temperature, compared to 0.87 obtained with the unpromoted $\mathrm{Sr} / \mathrm{La}_{2} \mathrm{O}_{3}$.

Thus, as shown, the performance of the $\mathrm{Sr} / \mathrm{La}_{2} \mathrm{O}_{3}$ catalyst in the partial oxidation of $\mathrm{CH}_{4}$ to $\mathrm{C}_{2}$ products can be selectively modified by doping this catalyst with 0.5 wt $\mathrm{Sb}$ or 0.5 wt $\mathrm{Fe}$. The contrast observed at temperatures lower than $650^{\circ} \mathrm{C}$ between the performance of both dopants indicates that the promoter- $\mathrm{Sr} / \mathrm{La}_{2} \mathrm{O}_{3}$ surface interaction is specific and selective. Although both $\mathrm{Fe}$ and $\mathrm{Sb}$ increased $\mathrm{CH}_{4}$ conversion, their effect on the selectivity to $\left(\mathrm{C}_{2}=+\mathrm{C}_{2}\right)$ were dramatically opposite (Table 1), i.e. Fe decreased and Sb increased selectivity.

Iron thus behaves as a non-selective oxidation component, similar to $\mathrm{FeO}_{\mathrm{x}}$ (21). No selectivity switch to oxygenates due to the presence of Fe was observed in the present system as contrary to the Fe-doping of $\mathrm{ZnO}$ (22). The latter could be due to (i) much higher activity of the present base $\mathrm{Sr} / \mathrm{La}_{2} \mathrm{O}_{3}$ catalyst for $\mathrm{C}_{2}$ coupling and (ii) different dispersion and thereby chemical state of the Fe dopant on the surface of $\mathrm{Sr} / \mathrm{La}_{2} \mathrm{O}_{3}, \mathrm{e} . \mathrm{g}$. vs the lattice structure controlling surface siting and geometry of the Fe dopant in Zno (23).

Beciase Sb significantly increased both activity and selectivity, we consider this dopant to be an important improvement of the $\mathrm{Sr} / \mathrm{La}_{2} \mathrm{O}_{3}$ catalyst. 
By ESCA analysis (24), the Sb surface concentration was 378 , implying all of the dopant. was dispersed on the surface, not in the bulk. The $4 \mathrm{~d}_{3 / 2} \mathrm{YPS}$ photoemission peaks are asymmetric, indicating coexistent of $\mathrm{Sb}^{\mathrm{III}}$ and $\mathrm{Sb}^{\mathrm{V}}$. Two properties of $\mathrm{SbO}_{x}$ have to be considered to explain the promotion effect: $\mathrm{Sb}^{\mathrm{III}} / \mathrm{Sb}^{\mathrm{V}}$ is a redox system and a similar class of redox promoters $\left(\mathrm{SbO}_{\mathrm{x}}, \mathrm{SnO}_{\mathrm{x}}\right)$ was found : o be effective for promotion of the Li/Mgo catalyst (19), and in the Sn system, kinetic analysis (25) indicated enhancement of oxygen chemisorption, and (ii) $\mathrm{SbO}_{\mathrm{x}}$ materials are also acidic oxides, and are used here to dope a strongly basic $\mathrm{Sr} / \mathrm{La}_{2} \mathrm{O}_{3}$ system. The acid-base interaction is expected to be strong and responsible for the spreading of the $\mathrm{Sb}$. It could also neutralize chemical species that poison the $\mathrm{Sr} / \mathrm{La}_{2} \mathrm{O}_{3}$ oxide such as $\mathrm{CO}_{3}{ }^{*}, \mathrm{OH}^{-}$, or $\mathrm{HCO}_{3}{ }^{*}$, rendering the active sites operational. The nature of these active sites is still uncertain and sect to further investigations. Preliminary results with $\mathrm{Sn}, \mathrm{Bi}, \mathrm{Pb}$, and $\mathrm{P}$ indicate that the Sb-effects are general for that class of dopants .

\section{REFERENCES}

1. C.H. Lin, K.D. Campbe11, J.X. Wang and J.H. Lunsford, J. Phys. Chem., 90, 534 (1986).

2. J.M. DeBoy and R.F. Hicks, J.Catal, 113, 517 (1988).

3. J.M. DeBoy and R.F. Hicks, Ind. Eng. Chem. Res., 27, 1577 (1988).

4. G.J. Hutchings, M.S. Scurrel1 and J.R. Woodhouse, Chem. Soc. Rev, 18, 251 (1989).

5. Y. Amenomiya, V.I. Birss, M. Goledzinowski, J. Galuszka and A. Sanger, Catal.Rev,-Sci. Eng,, 32(3), 163 (1990).

6. J.S. Lee and S.T. Oyama, Catal, Rev.-Sci. Eng., 30(2), 249 (1987).

7. R. Pitchai and K. Klier, Catal. Rev.-Sci. Eng., 28(1), 13 (1986).

8. T. Ito, J. Wang, C. Lin and J.H. Lunsford, J. Am. Chem. SoC., 107, 5062 (1985). 
9. C. Lin, J. Wang and J.H. Lunsford, J. Catal., 111, 302 (1988).

10. K. Otsuka, K. Jinno and A. Morikawa, J. Catal., 100, 353 (1986).

11. J.M. DeBoy and R.F. Hicks, J. Chem. Soc., Chem, Commun., 982 (1988).

12. J.A. Sofranko, J.J. Leonard and C.A. Jones, J.Catal., 103, 302 (1987).

13. G.E. Keller and M.M. Bhasin, J.Cata1., 73, 9 (1982).

14. I.T.A. Emesh and Y. Amenomiya, J. Phys. Chem., 90, 4785 (1986).

15. M.Y. Lo, S.K. Agarwal, L.G. Galya and G. Marcelin, Catal. Today, 3, 137 (1988).

16. K. Otsuka, K. Jinno and A. Morikawa, Chem, Lett., 499 (1985).

17. K. Asami, S Hashimoto, T. Shikada, K. Fujimoto and H. Tominaga, Ind. Eng. Chem. Res., 26, 1485 (1987).

18. W. Hinnen, W. Bytyn and M. Baerns, Proc. 8th Intern. Congr. Catal., 3, 581 (1984).

19. S.J. Korf, J.A. Roos, L.J. Veltman, J.G. van Ommen and J.H. Ross, Appl. Catal., 56, 119 (1989).

20. S. Bartsch and H. Hofman, Catal. Today, 6, 527 (1990).

21. M. Hatano and K. Otsuka, Inorg. Chim. Acta, 146, 243 (1988).

22. Z. Sojka, R.G. Herman and K. Klier, J. Chem. Soc., Chem. Comm, 185 (1991).

23. Z. Sojka and K. Klier, J.Elect. Spect. Rel. Phenom., (1992); in press.

24. J.I. Di Cosimo, R.G. Herman and K. K1ier, to be published.

25. S.J. Korf, J.A. Ross, J.A. Vreeman, J.W.H.C. Derksen, J.G. van Ommen and J.R.H. Ross, Catal. Today, 6, 417 (1990). 

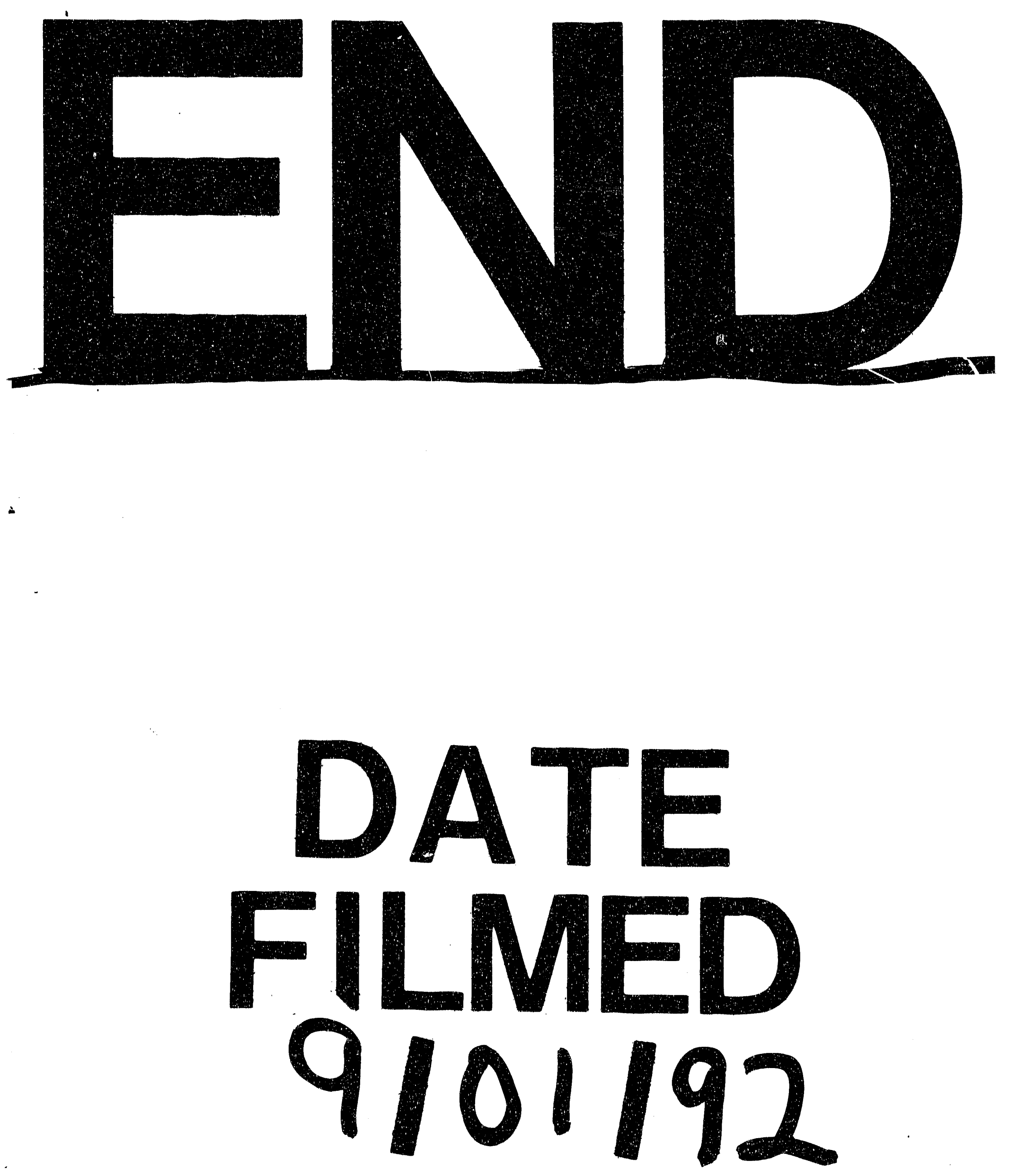


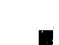

